\title{
原＼cjkstart著＜wide>大阪市街地の都市緑地の樹林を利用する鳥類を決定する要因
}

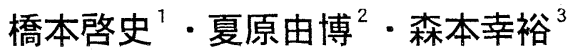 \\ 京都大学大学院農学研究科 606-8502 京都市左京区北白川追分町 \\ (hashi@kais.kyoto-u.ac.jp) \\ ${ }^{2}$ 大阪府立大学大学院農学生命科学研究科 599-8531 堺市学園町 1-1 \\ (natuhara@envi.osakafu-u.ac.jp) \\ 3 京都大学地球環境学大学院 606-8502 京都市左京区北白川追分町
} (ymo@kais.kyoto-u.ac.jp)

\section{The factors affecting land birds in urban parks of Osaka}

\author{
Hiroshi Hashimoto ${ }^{1}$, Yosihiro Natuhara ${ }^{2}$ and Yukihiro Morimoto ${ }^{3}$ \\ ${ }^{1}$ Graduate School of Agriculture, Kyoto University, Kitashirakawa Oiwake-cho, Sakyo-ku, Kyoto, 606- \\ 8502 Japan. ${ }^{2}$ Graduate School of Agriculture and Biological Sciences, Osaka Prefecture University, 1-1 \\ Gakuen-cho, Sakai, Osaka, 599-8531, Japan. ${ }^{3}$ Graduate School of Global Environmental Studies, Kyoto \\ University, Kitashirakawa Oiwake-cho, Sakyo-ku, Kyoto, 606-8502 Japan.
}

\begin{abstract}
Bird survey was conducted in 85 urban parks in the breeding season of 2000 in Osaka city, western Japan, to clarify the factors affecting bird species richness and bird community in urban small parks. Eleven species of land birds were observed. As the result of comparison of goodness of fit between a species$\log$ area and a species-log tree area curve, the former fitted better. We made a multiple regression analysis to predict the number of species in the urban parks. Tree area of parks was a positive factor, whereas areas of streets, offices and commercial buildings were negative factors affecting species richness. But the obtained model fit less than that of an earlier study in Osaka Prefecture. The reason may be related to the small number of bird species in urban parks in the central area of Osaka city. Bird communities were classified using TWINSPAN. We recognized three types of bird species groups, such as, "urban birds", open habitat species and forest species. The result of a discriminant analysis showed that tree area positively affected bird communities in urban parks. Street coverage, and office and commercial building coverage had negative effects. Busy streets and tall buildings will interfere bird movement. We suggest the minimum area of tree stands required for creating adequate habitat for forest birds in an urban area may be about 5 ha.
\end{abstract}

Key Words: bird community, multivariate statistics, Osaka, species-area relationship, urban parks

\section{はじめに}

都市において野鳥などの多様な生物が生息するこ とは，複雑な食物網が形成され，生態系のバランス が保たれることにつながる。また，野鳥の生息は都 市住民の生活にうるおいをあたえる。

都市緑地や孤立林の面積などと鳥類の種数や種組 成との関係については，これまでにも国内外で多く の報告がある（樋口ら 1982 ; Natuhara and Imai 1999； Fernández-Juricic and Jokimäki 2001)．大阪の都市緑 地についても Natuhara and Imai (1999) や和田 (1999) の報告がある．しかし標準面積が $0.25 \mathrm{ha}$ の街区公園 （児童公園）規模の都市緑地は，鳥類の生息地とし てあまり重要視されてこなかつたため，小規模な都 市緑地の鳥類相を規定する要因については充分に明 らかにされているとは言えない.しかし，新たな大 緑地を創出することが困難な市街地において生物相 を豊かにするには，街区公園や近隣公園（標準面 2.0ha）規模の緑地の整備が中心的な役割を果たすこ とになる。また，市街地全体を生態学的に健全な状 態にするためには小規模緑地の活用が必要となる.

本研究では, 大阪市街地の $0.1 \mathrm{ha}$ 程度の街区公園 か135ha の大規模緑地までを含んだ都市緑地におい， て鳥類相を調査し, 小規模緑地を含んだ市街地の都 市緑地の鳥類種数および種組成を決定する要因を分 析した. 都市緑地内に生息する鳥類の種数について は, 緑地面積との回帰分析およびステップワイズ重 回帰分析による環境要因の探索をおこなつた。種組 成については, TWINSPAN によつて鳥類群集を分類 したのち, 判別分析によって環境要因から鳥類相を 予測する式をもとめた。 なお，貧弱な鳥類相の場所 の評価には個体数は適当ではなく, 種数や種組成を もちいることが望ましいことが，大迫（1992）によ つて指摘されている。

分析対象は繁殖期の樹林性鳥類とした. 一般的に 日本の都市緑地では，繁殖期よりも越冬期の方が多 様な野鳥が観察される。しかし, 繁殖期の樹林性鳥 類相哖変動が少なく，また鳥類が生息することで 昆虫の発生数が抑えられるなど（Sanz 2001）, 都市 生態系の健全性の指標となっていると考えられる。 なお，冬鳥や渡りの途中の種と明らかに判断できる 種が記録された場合は，分析対象から除いた。

本研究をおこなうにあたり，大阪府環境農林水産 
部緑整備室に空中写真閲覧の許可をいただいた．大 阪府立大学大学院の前中久行教授および中村彰宏助 手には本論をまとめる際に助言をいただいた.また, 京都府立大学大学院生（当時）の長瀬興氏には自作 の『細密数值情報土地利用』デー夕変換プログラム を提供いただいた，以上の皆様に感謝します.

\section{調查地および方法}

\section{1. 調査地}

研究対象地は, 大阪府大阪市の淀川以南および堺 市北部の 85 か所の都市緑地（公園・社寺）とした. 緑地の敷地面積は $0.1-135 \mathrm{ha}$, 平均 5.5 $\pm 17.67 \mathrm{ha}$ であ る.この地域はかつて淀川の氾濫原で低湿地となつ ていたため, 一部の台地上には森林が存在したが, 樹林のほとんどは植栽されたものである，現在，緑 地周囲の土地利用は，オフィスビル街や低層密集住 宅地，中高層住宅地などが主となっている．堺市内 の中高層住宅団地は，比較的緑が多い住宅地となっ ている。

\section{2. 現地調査}

現地調査は, 2000 年 4 月 29 日から 7 月 20 日の間 の晴天日の 6 時から 13 時の間に, 各調査地につき 2 回ずつおこなつた，鳥類の記録には, 緑地内のほぼ 全域を時速約 $2 \mathrm{~km}$ で歩きながら出現種を記録するう インセンサス法をもちいたが, 観察距離が遠い個体 も記録に含めた。 また，上空通過個体や緑地外約 50 $\mathrm{m}$ 以内の出現個体も，おもにその緑地を利用してい るものとみなして記録に含めた. 観察には 10 倍の双 眼鏡を補助的にもちいた.

\section{3. 環境要因}

緑地内およびその周囲の樹冠投影図は, 1994 年撮 影の空中写真（大阪府緑整備室所有）をイメージス キャナーで取り込み, 画像処理ソフト ERDAS IMAGINE Ver. 8.3（ERDAS 社製）で簡易オルソ補正 をしたのち，GIS ソフト ArcView 3.1 (ESRI 社製) 上でトレースして作成した。樹冠直径 $1 \mathrm{~m}$ 程度の街 路樹や個人住宅内の樹木も読夕取った. 樹冠投影図 からは, 緑地内樹冠面積 $(\mathrm{G})\left(\mathrm{m}^{2}\right)$ を計測した.また, 緑地周囲の樹木量として, 緑地の敷地境界から $100 \mathrm{~m}$ および $200 \mathrm{~m}$ のバッファを発生させ, バッファ内の 樹木率\% $\left(\mathrm{G}_{100}, \mathrm{G}_{200}\right)$ を算出した. 緑地（公園・社 寺）の敷地面積 (A) $\left(\mathrm{m}^{2}\right)$ や周囲長 (P) (m)も同様に 空中写真をもとに計測した. 緑地の形状の指標とし $\tau$, 面積亡周囲長から算出される形状指数 $K=P / 2 \downarrow$

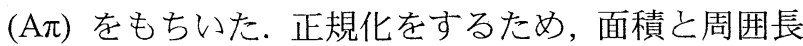
は常用対数変換, 樹木率は平方根変換したのち逆正 弦変換をおこなつた值をもちいた。なお，緑地の敷 地面積之周囲長は，緑地内樹冠面積之の間で高い相 関をもつたため，本研究では樹林性の鳥類を分析対 象としていることから，重回帰分析と判別分析には 緑地内樹冠面積のみを変数とし, 緑地の敷地面積と 周囲長は変数としてもちいなかった.

緑地周囲の土地利用については，国土地理院発行 の『近畿圈版細密数值情報 $10 \mathrm{~m}$ メッシュ土地利用 （1996）』を GIS に取り込み，凡例を統廃合して利 用した。緑地の敷地境界から $100 \mathrm{~m}$ および $200 \mathrm{~m} の$ バッファを発生させ, バッファ内の土地利用タイプ ごとの面積割合（\%）を読夕取り，平方根変換した のち逆正弦変換をおこなつた值をもちいた．分析に は, 調査対象地周辺に少ない土地利用タイプや多様 な土地被覆を含む凡例（例えば公共用地）を除き， 低層住宅地率 (LR), 中高層住宅地率 (TR), 商業・ 業務用地率 $(\mathrm{CO})$, 道路用地率 $(\mathrm{RO})$ をもちいた. 一般低層住宅地と密集低層住宅地は, 庭の有無など に違いがあると考えられるが，庭木などは樹冠投影 図から読み取っているので, 凡例を統合した。低層 住宅地亡中高層住宅地は, 野鳥が移動する際の見通 しや飛行高度に対する影響が異なると考えられるた め, 統合しなかつた. 商業・業務用地には, 店舗の ほかにオフィスビルなども含まれている，道路用地 には, 阪神高速道路などの高架上の道路も含まれて いる。

樹林性鳥類の供給源と考えられる山地の連続した 森林からの距離（D）を, 本調査地の東に位置する 生駒山地の連続した森林からの距離として, GIS ソ フト上で細密数值情報土地利用図から $0.1 \mathrm{~km}$ 単位で 計測した. また, 樹冠面積 10ha 以上の大規模緑地 (3 か所; 1 か所以調査対象外の緑地) からの距離 $\left(\mathrm{D}_{10}\right)$ も $0.1 \mathrm{~km}$ 単位で計測した。なお大規模緑地自身の $\mathrm{D}_{10}$ は $0 \mathrm{~km}$ とした。

緑地の開設からの経過年数 (Y) は, 文献 (大阪 府土木部公園課 2001) から読夕取り, 10 年単位で 0 -9 年までを 10,90 年以上を 100 とした。

\section{4. 分析方法}

\section{(1) 種数}

まず，樹林性鳥類の種数と緑地の敷地面積および 緑地内樹冠面積との回帰式をもとめた. 面積は常用 対数変換をおこなっているので Gleason（1922）の 片対数モデルと同じ形の式である．ただし，面積の 
空中写真をもとに計測した。緑地の形状の指標とし 計測単位は平方メートルであるため, 多くの研究で 示されているへクタール単位の面積をもちいた回帰 式との係数の大小の比較には注意が必要である.

次に, ステップワイズ重回㷌分析によって, 種数 を決定する環境要因を明らかにした. 重回帰式は, 線形重回帰モデル (ただし樹冠面積は常用対数), 指 数関数モデル, ロジスティック回帰モデルの 3 種類 を，それぞれ最小二乗法をもちいて作成し，自由度 調整済み決定係数が最大となるモデルを最もあては まりのよいモデルとして採用した. 指数関数モデル， ロジスティック回帰モデルは，式をそれぞれ式 2, 式3のように変形してもとめた.

$\mathrm{S}=\mathrm{b}_{0}+\mathrm{b}_{1} \mathrm{x}_{1}+\mathrm{b}_{2} \mathrm{x}_{2}+\ldots+\mathrm{b}_{\mathrm{n}} \mathrm{x}_{\mathrm{n}}$

(式 1 ; 直線回帰モデル)

$\ln \mathrm{S}=\mathrm{b}_{0}+\mathrm{b}_{1} \mathrm{x}_{1}+\mathrm{b}_{2} \mathrm{x}_{2}+\ldots+\mathrm{b}_{\mathrm{n}} \mathrm{x}_{\mathrm{n}}$

(式 2 ; 指数関数モデル)

$\ln [\mathrm{S} /(\mathrm{k}-\mathrm{S})]=\mathrm{b}_{0}+\mathrm{b}_{1} \mathrm{x}_{1}+\mathrm{b}_{2} \mathrm{x}_{2}+\ldots+\mathrm{b}_{\mathrm{n}} \mathrm{x}_{\mathrm{n}}$

(式 3 ; ロジスティック回帰モデル)

$(\mathrm{S} ;$ その調查地における分析対象種数, $\mathrm{k}$; 分析対 象全調査地内の分析対象種数）

独立変数は前節で用意した環境要因をもちいたが, 互いに相関の高い変数が同じ式に入らないよう，以 下の手順によって重回帰分析でもちいる変数を採用 した. まず種数との間の相関係数の絶対値が高いも のから順に变数として採用する。ついで, 採用され た変数間で相関係数の絶対值が 0.5 以上ある採用順 位が低い変数は除外する。この手順を繰り返し，全 ての変数について採用の可否を検討した. 重回帰式 の説明変数の選択は $\mathrm{F}_{- \text {in }}=2.0, \mathrm{~F}_{\text {-out }}=1.9$ とする前進ス テップワイズ法でおこなつた。樋口ら（1982）は, 面積 $1.0 \mathrm{ha}$ 未満の森林では種数と面積の関係が不明 瞭になることを明らかにしている，そこで重回帰モ デルは，全調査地を分析対象としたモデルに加え，

1.0 ha 未満の樹冠面積の緑地（n=61）を対象とした モデル, および 1.0 ha 以上の樹冠面積の緑地 $(\mathrm{n}=24)$ を対象としたモデルをそれぞれ同様の手順で作成し， 3 種類ずつ, 計 9 個の回帰式を作成した.

\section{(2)種組成}

2 回の調査におけるそれぞれの種の出現頻度 $(0,1$ または 2)をもとに, TWINSPAN（Hill, 1979）によ って第 3 分割までおこない, 調査地点を 4 グループ に分類した．ついで多群の判別分析によって，鳥類 相を決定する環境要因を探った，独立変数は，種数 の重回帰式 ( 3 種 )で選択された環境要因のうち,
全調査地を対象とした式, 樹冠面積 1 ha 未満の緑地 を対象とした式, 樹冠面積 1ha 以上の緑地を対象亡 した式, の優先順位で, 相関係数の絶対值が 0.5 以 上の他の変数を除いた変数をもちいた．説明変数の 選択は $\mathrm{F}_{\text {-in }}=2.0, \mathrm{~F}_{\text {-out }}=1.9$ とするステップワイズ法で おこなつた，選択された環境要因について，それぞ れのグループ内の值を比較した.

\section{1. 出現種数}

\section{結 果}

\section{(1)種数と面積の関係}

全調査地 ( $\mathrm{n}=85)$ における全出現種数は 31 種 (平 均 $6.1 \pm 3.26$ 種), 分析対象となる樹林性鳥類種数は 11 種（平均 $5.3 \pm 2.03$ 種）であった（表 1 ）。また, 樹冠面積 1 ha 未満の緑地における分析対象種数は 9 種であった.なお，樋口ら（1982）はドバトColumba livia を樹木に依存しない種として扱っているが, 本 種は樹木にも止まり，また樹上ではないが他種との 餌の競合関係から種組成に影響をあたえていると考 えられるため, 分析対象種に含めた.

種数之面積の関係は, 図 2 のようになり, 以下の 2 式が得られた。

$$
\begin{aligned}
& \mathrm{S}=2.319 \log \mathrm{A}-4.372 \quad\left(\mathrm{R}^{2}=0.542, \mathrm{P}<0.001\right) \quad \text { (式 4) } \\
& \mathrm{S}=2.165 \log \mathrm{G}-2.707 \quad\left(\mathrm{R}^{2}=0.471, \mathrm{P}<0.001\right) \quad \text { (式 5) } \\
& \text { ごちらも有意な式となつたが, 決定係数は種数と }
\end{aligned}
$$
緑地の敷地面積との間の回帰式の方が高かった。緑 地内樹冠面積と種数との関係をしめす散布図（図 1 b) を見ると，種数は樹冠面積 5 ha 程度において 10 種に達し，頭打ちとなっていた。また，樹冠面積が 小さい緑地ほど，種数と面積の関係が不明瞭になる 傾向があった.

\section{(2)種数に関する重回帰分析結果}

ステップワイズ重回帰分析の結果, 表 2 にしめす 式が得られた。検討した変数は, 全調査地を対象と した式では, 緑地内樹冠面積, $100 \mathrm{~m}$ バッファ内商業 地率, $200 \mathrm{~m}$ バッファ内道路用地率, 形状指数, $10 \mathrm{ha}$ 以上の樹林からの距離, $100 \mathrm{~m}$ バッファ内の中高層住 宅地率, $100 \mathrm{~m}$ バッファ内の低層住宅地率であった. 樹冠面積 $1 \mathrm{ha}$ 未満の緑地を対象とした式では, $100 \mathrm{~m}$ バッファ内の樹木率, $200 \mathrm{~m}$ バッファ内の商業地率, 緑地内樹冠面積, $100 \mathrm{~m}$ バッファ内の道路用地率, $100 \mathrm{~m}$ バッファ内の中高層住宅地率, $200 \mathrm{~m}$ バッファ 内の樹木率, 形状指数, 開設後経過年数, $10 \mathrm{ha}$ 以上 の樹林からの距離, $100 \mathrm{~m}$ バッファ内の低層住宅地率 であった．樹冠面積1 ha 以上の緑地を対象とした式 
表 1．各緑地において記録された鳥類の種類とその頻度.

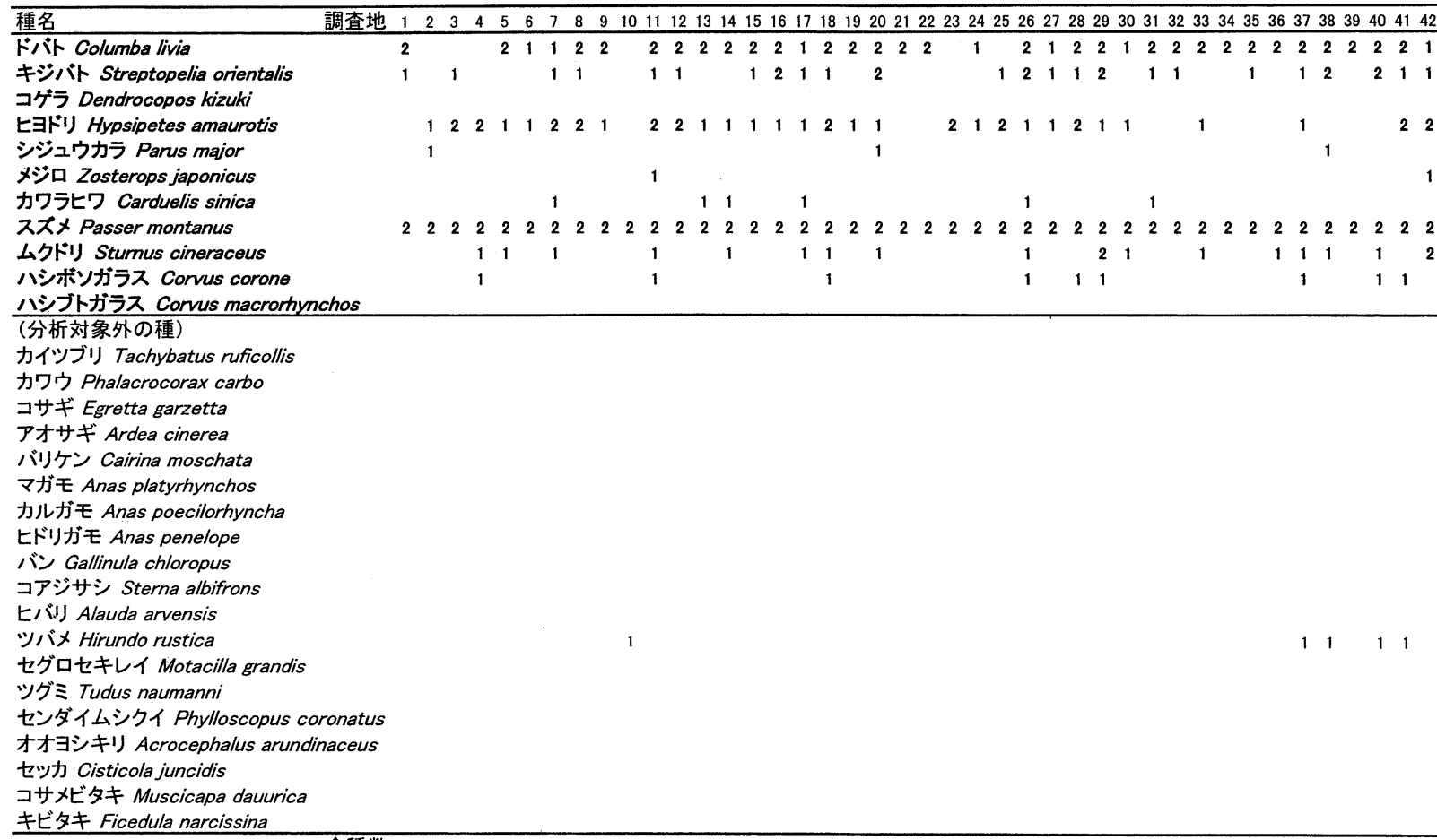

全種数 $3 \begin{array}{llllllllllllllllllllllllllllllllllllllllll} & 3 & 3 & 4 & 4 & 3 & 6 & 4 & 3 & 2 & 7 & 4 & 4 & 5 & 4 & 4 & 6 & 6 & 3 & 6 & 2 & 2 & 2 & 3 & 3 & 7 & 4 & 5 & 6 & 4 & 4 & 3 & 4 & 2 & 3 & 3 & 7 & 6 & 2 & 6 & 6 & 6\end{array}$ 和象種数 $3 \begin{array}{lllllllllllllllllllllllllllllllllllllllllll} & 3 & 3 & 4 & 4 & 3 & 6 & 4 & 3 & 1 & 7 & 4 & 4 & 5 & 4 & 4 & 6 & 6 & 3 & 6 & 2 & 2 & 2 & 3 & 3 & 7 & 4 & 5 & 6 & 4 & 4 & 5 & 4 & 2 & 3 & 3 & 6 & 5 & 2 & 5 & 4 & 6\end{array}$

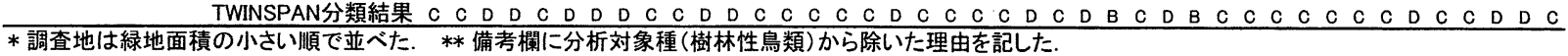

\begin{tabular}{|c|c|c|c|c|c|c|c|c|c|c|c|c|c|c|c|c|c|c|c|c|c|c|c|c|c|c|c|c|c|c|c|c|c|c|c|c|c|}
\hline & 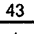 & & & & & & & & & & & & & & & & & 263 & & 6566 & 6768 & 6869 & 970 & & & 374 & & 677 & 78 & $\varepsilon$ & & & 328 & & 85 & 現 & 備考 \\
\hline ドパト & 1 & 2 & 2 & 2 & 2 & 2 & 2 & 2 & 2 & 2 & 2 & 2 & 22 & 1 & 1 & 2 & 22 & 1 & 22 & 22 & 22 & 21 & 2 & 2 & 22 & 2 & 22 & 22 & 2 & 2 & 22 & 22 & 22 & 2 & 2 & $78(91.8)$ & \\
\hline キジハト & & 2 & 1 & & & 1 & 2 & 1 & 2 & 1 & 2 & 2 & 1 & 1 & & 2 & 12 & 1 & 21 & 12 & 22 & 21 & 2 & & 21 & 1 & 11 & 2 & 2 & 1 & 22 & 22 & 22 & 2 & 2 & $61(71.8)$ & \\
\hline コゲラ & & & & & & & & & & & & & & & & & & & & & & 1 & & & & & & & & 1 & & 1 & & & 2 & $4(4.7)$ & \\
\hline ヒヨドリ & & & 1 & 1 & 2 & 1 & 1 & 21 & 2 & 2 & 2 & 2 & 11 & 2 & 2 & 2 & 21 & 2 & 12 & 21 & 22 & 21 & 2 & 2 & 22 & 2 & 22 & 22 & 2 & 2 & 12 & 22 & 22 & 2 & 2 & $71(83.5)$ & \\
\hline シジュウカラ & & & & & & & & & & & & 1 & & & & & & & 21 & 1 & & & 1 & & & & & & & 1 & & 11 & 11 & 1 & 1 & $13(15.3)$ & \\
\hline メジロ & & & & & & & 1 & & & & 1 & 1 & & & 1 & 1 & & & & 1 & & & 1 & & 1 & & & & & 2 & & 1 & 1 & 2 & 2 & $15(17.6)$ & \\
\hline カワラヒワ & 1 & & 1 & & & & 1 & & & & & 1 & & & 1 & 1 & 1 & 1 & & 2 & 21 & 1 & & 1 & 11 & & & 1 & 1 & 1 & 1 & & 22 & 1 & 1 & $28(32.9)$ & \\
\hline ススx & 2 & 2 & 2 & 2 & 2 & 2 & 2 & 22 & 2 & 2 & 2 & 22 & 22 & 2 & 2 & 2 & 22 & 2 & 22 & 22 & 22 & 22 & 2 & 2 & 22 & 2 & 22 & 2 & 2 & 2 & 22 & 22 & 22 & 2 & 2 & $85(100)$ & \\
\hline ムクドリ & 1 & 1 & 1 & & 1 & 1 & & 1 & & 1 & 2 & 1 & 12 & 2 & 2 & & 21 & 2 & 22 & 22 & 22 & 21 & 1 & 1 & 22 & 2 & 21 & 2 & 2 & 1 & 22 & 22 & 22 & 2 & 2 & $55(64.7)$ & \\
\hline $\begin{array}{l}\text { ハシボソガラス } \\
\text { ハシブトガラス }\end{array}$ & & & 1 & & 1 & & 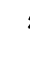 & 2 & & 2 & & 1 & 1 & 1 & 2 & 1 & 12 & 2 & 21 & 11 & 21 & 11 & 2 & 1 & 11 & & 1 & 1 & 1 & 1 & 12 & 21 & 12 & 2 & 2 & 41(48.2) & \\
\hline \multicolumn{38}{|l|}{ (分析対象外の種) } \\
\hline カイツブリ & & & & & & & & & & & & & & & & & & & & & & & & & & & & 1 & & & & & & & & $1(1.2)$ & 水鳥 \\
\hline カワウ & & & & & & & & & & & & & & & & & & & & & & & & & & & & & & & & & & & 1 & $1(1.2)$ & 水鳥 \\
\hline コサギ & & & & & & & & & & & & & & & & & & & & & & & & & & & & & & & 22 & 2 & & & & $2(2.4)$ & 水鳥 \\
\hline アオサギ & & & & & & & & & & & & & & & & & & & 1 & & & & & 1 & & 1 & & 2 & & & 22 & 2 & & & 1 & $7(8.2)$ & 水鳥 \\
\hline パリケン & & & & & & & & & & & & & & & & & & & & & & & 2 & & & & & & & & & & & & & $1(1.2)$ & 水鳥 \\
\hline マガモ & & & & & & & & & & & & & & & & & & & & & & & 2 & & & & & 2 & & 1 & 2 & & & 1 & & $5(5.9)$ & 水鳥 \\
\hline カルガモ & & & & & & & & & & & & & & 1 & & & & & & & & & & & & & & & 1 & 1 & 12 & 21 & 11 & & & $7(8.2)$ & 水鳥 \\
\hline ヒドリガモ & & & & & & & & & & & & & & & & & & & & & & & 2 & & & & & & & & & & & & & $1(1.2)$ & 水鳥 \\
\hline パン & & & & & & & & & & & & & & & & & & & & & & & & & 2 & & & 1 & & & 2 & & & & & $3(3.5)$ & 水鳥 \\
\hline コアジサシ & & & & & & & & & & & & & & & & & & & & & & & 1 & & 1 & & & 1 & & & & & & & & $3(3.5)$ & 水鳥 \\
\hline ヒバリ & & & & & & & & & & & & & & & & & & & & & 1 & & & & & & & & & & & & 1 & & & $2(2.4)$ & 草原 \\
\hline ツバメ & & & & & & & & & & & & 1 & & & & & & 1 & 2 & 1 & & 1 & 2 & & 2 & 1 & & & 1 & 1 & 21 & 11 & 12 & 2 & 2 & $21(24.7)$ & 上空 \\
\hline セグロセキレイ & & & & & & & & & & & & & & & & & & & & & & & & & & & & & & & & & 1 & & 1 & $2(2.4)$ & 水辺 \\
\hline ツグミ & & & & & & & & & & & & & & & & & & & 1 & & & & & & & & & & & & & & & & 1 & $2(2.4)$ & 冬鳥 \\
\hline センダイムシクイ & & & & & & & & & & & & & & & & & & & 1 & & & 11 & & & & & & & & 1 & & 1 & & & & $5(5.9)$ & 通過鳥 \\
\hline オオヨシキリ & & & & & & & & & & & & & & & & & & & & & & & & & & & & & & & 1 & & & & & $1(1.2)$ & 水辺 \\
\hline セッカ & & & & & & & & & & & & & & & & & & & & & & & & & & & & & & & & & 1 & & & $1(1.2)$ & 草原 \\
\hline コサメビタキ & & & & & & & & & & & & & & & & & & 1 & & & & & & & & & & & & & & & & & & $1(1.2)$ & 通過鳥 \\
\hline キビタキ & & & & & & & & & & & & & & & & & & & & & & & & & & & & & & 1 & & & & & 1 & $2(2.4)$ & 通過鳥 \\
\hline & 4 & 4 & 7 & 3 & 5 & 5 & 6 & 5 & 4 & 6 & 6 & 9 & 46 & 7 & 7 & 7 & 76 & 9 & 118 & 88 & 810 & 107 & 13 & 7 & 711 & 17 & 65 & 512 & 9 & & & 14 & 114 & 11 & 16 & 全種数 & \\
\hline & 4 & 4 & 7 & 3 & 5 & 5 & 6 & 5 & 4 & 6 & 6 & 8 & 46 & 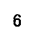 & 7 & 7 & 76 & 7 & 78 & 87 & 78 & 86 & 8 & 6 & 78 & 5 & 65 & 57 & 7 & 10 & & & 89 & 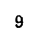 & 10 & 対象種数 & \\
\hline & C & & & & & & & 0 & & & & & $C \quad D$ & & B & & & & & C B & B B & $B \quad D$ & $A$ & B & & & & B & & & & & & & A & TWINSPAN & 分類結身 \\
\hline
\end{tabular}

調查地名

1 本庄南公園

2 阪南北公園

3 安倍清明神社

4 清明丘公園

5 玉川南公園

6 豊崎南公園

7 ABC公園

8 文の里公園

9 大淀南公園

10 稲生公園

\begin{tabular}{|c|c|c|}
\hline 1 阪南中公園 & 21 中津中央公園 & 31 䉆洲公園 \\
\hline 阿倍王子神社 & 22 空清町公園 & 32 城南公園 \\
\hline 石ヶ过公園 & 23 農人町公園 & 33 玉造公園 \\
\hline 中津南公園 & 24 苗代田公園 & 34 愛染公園 \\
\hline 中津東公園 & 25 玉造稲荷神社 & 35 滰川公園 \\
\hline 酒君塚公園 & 26 祭洲上公園 & 36 豊崎西公園 \\
\hline 7 杉本町公園 & 27 鷹合公園 & 37 北大江公園 \\
\hline 8 国分公園 & 28 駒川公園 & 38 清水谷児童公園 \\
\hline 東平公園 & 29 大淀中公園 & 39 越中公園 \\
\hline 小橋公園 & 30 銅座公園 & 40 上汐公園 \\
\hline
\end{tabular}

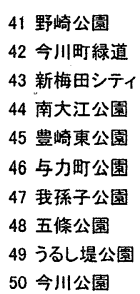

51 中大江公園
52 寺田町公園
53 山阪神社
54 清明丘中央公園
55 金岡東公園
56 本庄公園
57 高津公園
58 結堂公園
59 光童寺公園
60 沢之町公園

62 浦江公園

63 新金岡公園

64 三光神社

65 柴谷公園

66 下福島公園

67 浅香山公圈

68 白第公園

69 生玉公園

70 万代池公園

71 四天王寺

72 真田山公園

73 長池公園

74 難波宮跡公園

75 中之島公園

76 扇町公園

77 桃厅池公園

78 住吉公園

79 住吉大社

80 堺市·白鷖公園
81 天王寺公園

82 住之江公園

83 金岡公園

84 長居公園

85 大阪城公園 

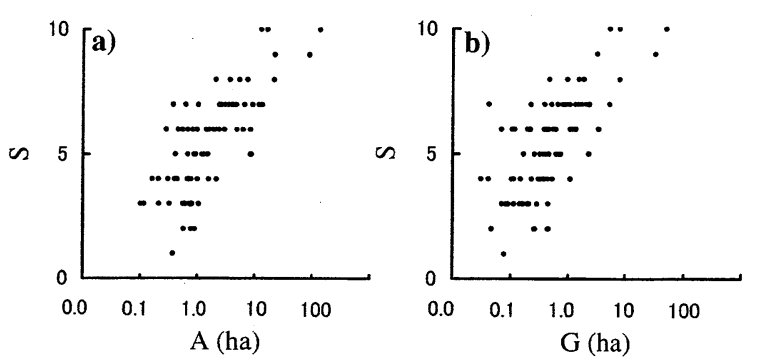

図 1. 樹林性鳥類の種数之面積の関係.

a) 種数(s), 一緑地面積 $(\mathrm{A})$

b) 種数(s), 一緑地内樹冠面積 $(\mathrm{G})$.

では, $100 \mathrm{~m}$ バッファ内の樹木率， $200 \mathrm{~m}$ バッファ内 の道路用地率, $10 \mathrm{ha}$ 以上の樹林からの距離, $100 \mathrm{~m}$ バッファ内の商業地率, $200 \mathrm{~m}$ バッファ内の低層住宅 地率, $200 \mathrm{~m}$ バッファ内樹木率, 開設後経過年数, 形 状指数であった．自由度調整済み決定係数の比較に より, 全調査地を対象とした式では線形回帰式が, 樹冠面積 1 ha 未満の調査地を対象とした式と樹冠面 積 1 ha 以上の調査地を対象とした式ではロジスティ ック回帰式が，それぞれ採用された.

選択された環境要因（括弧内に係数の正負をしめ す）は，全調査地を対象にした式では，緑地内樹冠 面積(+), $200 \mathrm{~m}$ バッファ内の道路用地率 $(-), 100 \mathrm{~m}$ バ ッファ内の商業地率(-), 10ha 以上の樹林地からの距 離(+)であった. 樹冠面積 1 ha 未満の調査地を対象に した式では, 緑地内樹冠面積(+), 200m バッファ内

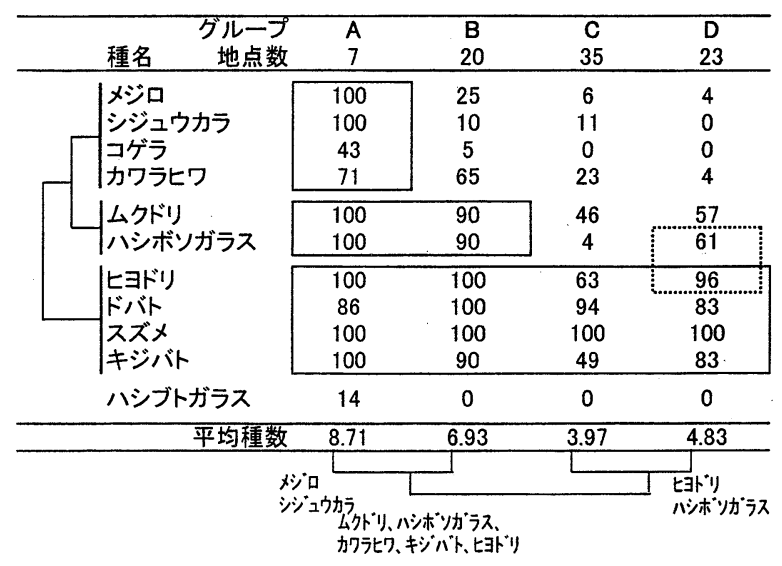

図 2.TWINSPAN による都市緑地の分類結果と各種 の出現率(\%)：分岐図の脇の種名は分割の際の 指標種をしめす。

の商業地率(-), 100m バッファ内の低層住宅地率(-), $100 \mathrm{~m}$ バッファ内の道路用地率(-), 10ha 以上の樹林 からの距離(+)であった．樹冠面積 1 ha 以上を対象之 した式では, $100 \mathrm{~m}$ バッファ内の樹木率(-), $200 \mathrm{~m}$ バ ッファ内の道路用地率(- ), 200m バッファ内の低層 住宅地率(+)であった。

\section{2. 種組成}

\section{(1)TWINSPAN による群集分類結果}

1 地点のみに出現したハシブトガラス Corvus macrorhynchos を除いた 10 種の出現頻度をもとに， TWINSPAN によって調査地点を 4 グループ (A, B, C，D）に分割した (図 2). 平均種数は A, B, D,

表 2. 得られた重回帰式の説明変数とその係数.

\begin{tabular}{|c|c|c|c|c|c|c|c|c|c|}
\hline \multirow[b]{2}{*}{ 説明変数 } & \multicolumn{3}{|c|}{ 全調査地 } & \multicolumn{3}{|c|}{ 樹冠面積1ha末渶 } & \multirow{2}{*}{\multicolumn{3}{|c|}{ 樹冠面積1ha以上 }} \\
\hline & $\mathrm{s}$ & $\ln S$ & $\ln [S /(k-S)]$ & $\mathrm{s}$ & $\ln S$ & $\ln [s /(k-S)]$ & s & & \\
\hline 定数項 & 1.424 & 0.924 & -1.656 & 4.657 & 1.444 & 0.128 & 14.314 & 3.036 & 3.663 \\
\hline $\mathrm{G}$ & 2.189 & 0.435 & 0.895 & 1.754 & 0.419 & 0.891 & - & - & \\
\hline$G_{100}$ & 一 & - & - & & & & -76.278 & -10.893 & -33.072 \\
\hline $\mathrm{G}_{200}$ & - & - & - & & & & & & \\
\hline $\mathrm{K}$ & & & & & & & & & \\
\hline Y & - & - & 一 & & & & & & \\
\hline Dio & 0.277 & 0.057 & 0.106 & 0.289 & 0.062 & 0.137 & & & 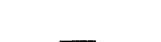 \\
\hline RO 100 & - & - & - & -5.577 & -1.567 & -2.856 & -6568 & $\overline{-1} 058$ & -2632 \\
\hline $\mathrm{RO}_{200}$ & -6.139 & -1.409 & -2.530 & 一 & - & - & -6.568 & -1.058 & -2.032 \\
\hline $\mathrm{CO}_{100}$ & -2.966 & -0.599 & -1.189 & - & - & - & & & \\
\hline $\mathrm{CO}_{200}$ & 一 & - & 一 & -5.642 & -1.081 & -2.887 & - & - & - \\
\hline TR100 & & & & & & & - & - & - \\
\hline TR200 & - & - & - & - & - & - & - & - & - \\
\hline $\begin{array}{l}\mathrm{LR} 100 \\
\mathrm{~L} 200\end{array}$ & & & & -2.101 & -0.388 & -1.058 & - & - & - \\
\hline$\underline{\mathrm{L}} 200$ & - & - & - & - & - & $=$ & 1.449 & 0.213 & 0.598 \\
\hline adjusted $R^{2}$ & 0.6016 & 0.4985 & 0.5980 & 0.4062 & 0.3303 & 0.4084 & 0.6401 & 0.6226 & 0.6420 \\
\hline
\end{tabular}

* S: 線形重回帰モデル, $\ln S:$ 指数関数モデル, $\ln [S /(k-S)]:$ ロジスティック回帰モデル

** G: 緑地内樹冠面積, G100:100mバッファ内樹木率, G200:200mバッファ内樹木率, K: 形状指数, $\mathrm{Y}$ :開設後経過年数, D 10: $10 \mathrm{ha}$ 以上の樹林からの距離, $\mathrm{RO} 100$ : 100mバッファ内道路用地率, RO200:200mバッファ内道路用地率, $\mathrm{CO} 100: 100 \mathrm{~m}$ バッファ内商業地率, $\mathrm{CO} 200: 200 \mathrm{~m}$ バッファ内商業地率,

TR100:100mバッファ内中高層住宅地率, TR200:200mバッファ内中高層住宅地率, LR 100:100mバッファ内低層住宅地率,

LR200:200mバッファ内低層住宅地率, adjusted $\mathrm{R}^{2}$ : 自由度調整済み決定係数 
表 3. 鳥類相によって分類された都市緑地グループの判別関数.

\begin{tabular}{lcrrrr}
\hline & \multicolumn{5}{c}{ 各グループの判別関数における説明変数の係数 } \\
\multicolumn{1}{c}{ 説明変数 } & $\mathrm{p}$ 値 & \multicolumn{1}{c}{$\mathrm{A}$} & \multicolumn{1}{c}{$\mathrm{B}$} & \multicolumn{1}{c}{$\mathrm{C}$} & \multicolumn{1}{c}{$\mathrm{D}$} \\
\hline 緑地内樹冠面積 & $<0.001$ & 18.8125 & 15.5621 & 12.2018 & 12.9924 \\
$200 \mathrm{~m}$ バッファ内道路用地率 & 0.011 & 51.5249 & 50.0000 & 61.9683 & 64.5550 \\
$100 \mathrm{~m}$ バッファ内商羙地率 & 0.082 & 6.8354 & 11.5701 & 17.5391 & 15.5914 \\
定数項 & & -59.2255 & -45.8753 & -42.4690 & -45.7686 \\
\hline
\end{tabular}

Wilks $の \wedge=0.428, F$ 値 $=8.918$, 自由度 $(9,192), P<0.001$

Cの順に多かつた. ヒヨドリHypsipetes amaurotis, ドバト, スズメ Passer montanus, キジバト Streptopelia orientalis は全てのグループに共通して高頻度で出 現した。ムクドリSturnus cineraceus，ハシボソガラ ス Corvus corone はA グループとBグループにおい て高頻度で出現した。 メジロ Zosterops japonicus, シ ジュウカラParus major, コゲラDendrocopos kizuki, カワラヒワ Carduelis sinica は A グループにおいて 高頻度で出現した。D グループは C グループより も，八シボソガラスとヒヨドリの出現頻度が高い傾 向があった。

\section{(2)判別分析結果}

判別分析で検討した変数は, 緑地内樹冠面積, $200 \mathrm{~m}$ バッファ内の道路用地率, $100 \mathrm{~m}$ バッファ内の 商業地率, $10 \mathrm{ha}$ 以上の樹林からの距離，100m バッ ファ内の低層住宅地率であった。ステップワイズ判 別分析の結果, 表 3 にしめす判別関数 $(\mathrm{P}<0.001)$ が 得られた. 選択された環境要因は, 緑地内樹冠面積,
表 4. 得られた判別関数の正判別率.

\begin{tabular}{|c|c|c|c|c|c|c|}
\hline \multirow[b]{2}{*}{ グループ } & \multirow[b]{2}{*}{$\mathrm{n}$} & \multicolumn{4}{|c|}{ 予測されたグループ } & \multirow{2}{*}{$\begin{array}{c}\text { 正判別率 } \\
(\%)\end{array}$} \\
\hline & & A & $\mathrm{B}$ & $\mathrm{C}$ & $\mathrm{D}$ & \\
\hline $\bar{A}$ & 7 & 5 & 2 & 0 & 0 & 71 \\
\hline B & 20 & 5 & 12 & 2 & 1 & 60 \\
\hline C & 35 & 0 & 3 & 21 & 11 & 60 \\
\hline D & 23 & 0 & 3 & 12 & 8 & 35 \\
\hline
\end{tabular}

$200 \mathrm{~m}$ バッファ内道路用地率であり, 判別関数のあて はまりのよさの指標である Wilks の $\Lambda$ は 0.428 であ つた。 また，観測值の判別結果を表4にしめした。 Dグループの正判別率が $35 \%$ と低い. 緑地内樹冠面 積一 $200 \mathrm{~m}$ バッファ内道路用地率の散布図（図 $3 \mathrm{a}$ ） および緑地内樹冠面積 $-100 \mathrm{~m}$ バッファ内商業地率 の散布図（図 $3 \mathrm{~b}$ ) をしめした。グループ A，B，D， C の順で緑地内樹冠面積が大きい傾向にあったが, CとDグループは似たような值をしめした，CとD グループは $200 \mathrm{~m}$ バッファ内の道路用地率，および $100 \mathrm{~m}$ バッファ内の商業地率も似た值をしめした。
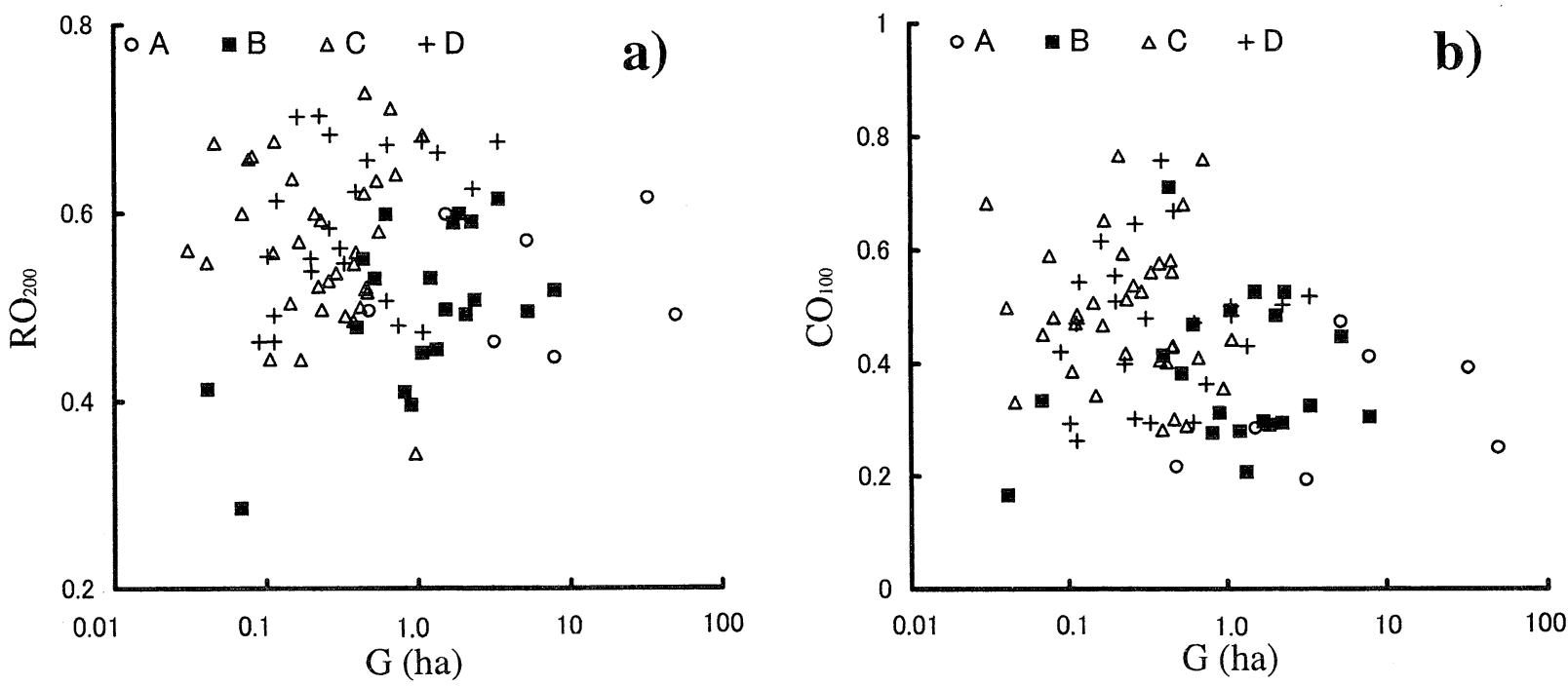

図 3. 判別分析において選択された環境要因の值の分布. a) 一緑地内樹冠面積 $(\mathrm{G}),-200 \mathrm{~m} ハ$ バッファ内道路 用地率 $\left(\mathrm{RO}_{200}\right)$ b) 一緑地内樹冠面積 $(\mathrm{G}),-100 \mathrm{~m}$ バッファ内商業地率 $\left(\mathrm{CO}_{100}\right)$. 道路用地率および商業地 率は逆正弦変換後の值。 


\section{考 察}

\section{1. 都市緑地の鳥類種数を決定する要因}

樹林性鳥類の種数と面積の相関は，樹冠面積より も，緑地の敷地面積と種数との間で高かった。この 原因としては，樹林性鳥類として分析対象とした種 に，主に開けた環境で採䬣する種が含まれていたこ とが考えられた。同じ近畿地方の京都の都市孤立林 においても森林内部種と言えるような鳥類はおらず

(Kurosawa and Askins 1999), 今回の分析対象種は疎 林性あるいは草地環境にも影響を受ける種であった. 例えば，ドバトやスズメは樹木が皆無の場所におい ても生息・繁殖することが可能である. キジバトや ハシボソガラスは樹木に営巣するが，採䬣環境は主 に開けた環境である。ムクドリは都市では建物の隙 間に営单し，樹上の果実の少ない繁殖期の餌は林床 や開けた地面の昆虫が主である。したがって，樹木 がまばらでも敷地面積の広い緑地で，これらの種が 出現したため, 緑地の敷地面積と種数との間の相関 が高くなつたと考えられた。

重回帰分析の結果, 全調查地, 樹冠面積 1 ha 未満 の緑地, 樹冠面積 1 ha 以上の緑地のいずれにおいて も有意な式 $(P<0.001)$ が得られたが, 自由度調整済 夕決定係数は 0.4 から 0.64 であり，大阪郊外のやや 大きい緑地も対象に含めた Natuhara and Imai (1999) の研究で得られた式のそれが 0.9 以上であったのと 比較すると，あてはまりはあまりよくなかった．こ の原因として，大阪市街地の繁殖期の樹林性鳥類相 が 11 種と非常に貧弱なため, 緑地間の種数の差が少 なく, 環境要因以外の偶然による 1,2 種の欠如が回 帰式のあてはまりに大きな影響を与えたことが考え られた。

全調査地を対象とした式と樹冠面積 $1 \mathrm{ha}$ 未満の緑 地を対象とした式において，それぞれ正の要因とし て緑地内樹冠面積が最も大きな要因として選択され た. 樹冠面積 1 ha 以上の緑地についての分析におい て, 緑地内樹冠面積が説明変数として選択されなか つた理由は, $100 \mathrm{~m}$ バッファ内の樹木率が最も大きな 負の要因となつており，これと緑地内樹冠面積の間 の相関係数が-0.5 以下であったため, 緑地内樹冠面 積は変数として分析にもちいなかったためである. $100 \mathrm{~m}$ バッファ内の樹木率は, 全調査地においても緑 地内樹冠面積と負の相関 $(\mathrm{R}=-0.67)$ があり, 種数 に対しても負の相関 $(\mathrm{R}=-0.68)$ があったことから， 樹冠面積 1 ha 以上の緑地を対象とした式で変数とし て選択された。周囲の樹木率が低い緑地において種 数が高かった理由として鳥類が緑地外に採餌に行く
頻度が低かつたことが考えられ，周囲の樹木率が高 いところでは緑地外に行く頻度の高い種を 2 回の調 査では記録できなかった可能性が考えられた。しか

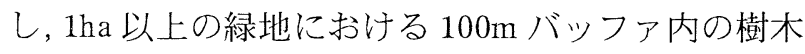
率と緑地内樹冠面積との間で強い負の相関 $(\mathrm{R}=-$ 0.80）があったことが示すように，単に大きな緑地 周辺の樹木率が低かつたためとも考えられる．1ha 以上の緑地におけ $100 \mathrm{~m}$ バッファ内の樹木率之種数 の相関係数は-0.67, 1ha 以上の緑地における緑地内 樹冠面積と種数の相関係数は 0.65 であり, 僅かな差 で重回帰分析の際に検討する変数に周囲の樹木率が

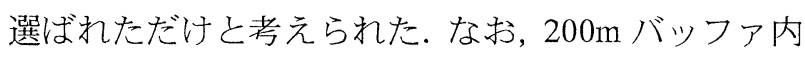
の樹木率は, 種数との間で弱い正の相関（R=0.34） があった．Natuhara and Imai（1999）が得た重回帰式 では，その緑地を含む $5 \mathrm{~km}$ 四方のメッシュ内の樹木 率が正の係数の説明変数として選択されている.お そらく個々の種によってその距離は異なるが, 緑地 からどれくらいの範囲の樹木が野鳥の生息に影響を 与えるかを明らかにすることは，今度の課題の一つ だろう。いくつかの種では生態観察によって行動圏 が報告されている．たとえば繁殖期のスズメの行動 半径は $200 \mathrm{~m}$ (佐野 1988) あるいは都会では巣から 500m も離れた䬶場に通う（唐沢 1989）. 定着個体の ヒヨドリの冬季の行動半径は $270 \mathrm{~m}$ から $453 \mathrm{~m}$ にな る (Fukui 1995). 繁殖期のカワラヒワは, 採餉のた めに巣から $300 \mathrm{~m}$ 程度の場所まで出かけていくこと がある（羽田・中村 1970）。キジバトは巣から 700m 以上離れた場所まで採慨に行く（羽田・野沢 1969）.

しかし, 森林のシジュウカラの行動圈は約 3ha とさ れるが (中村 1975)，樹木のまばらな都市における シジュウカラの行動圈は最大約 10ha にもなる (小河 原 1996) などと報告されているように, 環境によつ て行動範囲は大きく異なることがあり，都市におけ る行動範囲を知る必要がある。しかし全ての種につ いて環境別の行動圈を個体追跡によって明らかにす ることは非常に大変なことであるため, いくつかの 種について橋本・夏原（2002）のように統計的に生 息環境適合度モデルを作成する際に複数の距離の環 境要因を検討することが有効であると考えられる.

10ha 以上の樹林からの距離が, 全調査地を対象と した式と樹冠面 1 ha 未満の緑地を対象とした式にお いて正の要因として選択された，正の要因というこ とは，すなわち大緑地に近いほど種数が少ないとい うこと意味している.オランダの孤立林における鳥 類相を調べた Opdam ら（1984）は，種数の重回帰分 析をおこなつた結果，孤立林面積のほか，周囲 $3 \mathrm{~km}$ 
以内の森林面積や連続した森林からの距離に有意な 影響が見られたと報告している，スペインにおいて は, 古い都市公園の鳥類相は大規模緑地からの距離 の影響はないが，新しい公園の鳥類は大規模緑地か ら供給を受けているのではないかという報告もある

(Fernández-Juricic 2000b)。しかし，今回の結果は 逆であった。この理由は，樹冠面積 1 ha 以上の緑地 を対象とした式では選択されていないことから，都 市計画上の理由で大緑地の近くには小さい緑地しか ないためではない，種の供給源となる大緑地の基準 が, 樹冠面積 $10 \mathrm{ha}$ 以上で適当であるか, または今回 分析対象とした種に大緑地から供給されるような樹 林性の強い種がほとんど含まれていなかったためか 再検討する必要があるだろう。樹林性のシジュウカ ラ, メジロの分布を見てみると, 両種が出現した最 小樹冠面積の緑地は表 1 で 55 番の金岡東公園の 0.48ha であり, 大規模緑地からの距離は約 $300 \mathrm{~m}$ と 非常に近かった。しかしこれよりも樹冠面積の小さ い緑地でも，このうちの片方の種だけは出現してい た緑地がいくつもあり, 10ha 以上の樹冠面積の大規 模緑地との距離には依存していないように見える. シジュウカラの場合, 大規模緑地でなくても生息地 が複数近くにあると, 樹冠面積が小さくてもシジュ ウカラが生息していることがあった（橋本・夏原 2002).

欧米の都市緑地における鳥類種数についての研究 例を整理した Clergeau ら（2001）は, 緑地内の鳥類 の種数は隣接する景観の影響を受けることは少ない と結論しているが, 今回の例では, 周囲の道路用地 率之商業地率が, 緑地内の樹林性鳥類の種数に負の 影響をおよぼしていることが明らかになった。 Clergeau ら（2001）の例では, 面積が 4ha から 10ha の緑地を対象としているが, 本研究のように $1 \mathrm{ha}$ 末 満の小規模な緑地も含めた場合は，1 つの緑地で 1 個体の生活が完結しないため, 周囲の土地利用も影 響するだろう。街路樹のある道路は野鳥の移動経路 となることもあるが，野鳥は交通量の多い道路をあ まり利用しない（Fernández-Juricic 2000a）。大阪の 市街地の大通りは交通量が多く, また高架式の自動 車専用道路も道路用地率に算入されている. したが つて道路は，野鳥にとって都市緑地を周囲から分断 する要素と考えられる. 一方の商業地率が負の要因 となった理由は, 高層建築物の多さや人や自動車の 通行量の多さと関係があると考えられた. Clergeau ら（2001）は, 市街化が都市緑地内の鳥類種数と負 の相関があることを報告している. $200 \mathrm{~m}$ バッファ内
の商業地率の高さは市街地化の進んだ地区であるこ とを意味していると考えられるので, 今回の結果は, 市街地の中心部ほど野鳥の種数が少なくなることを しめしていると考えられた。

周囲の低層住宅地率が，樹冠面積 1 ha 未満の緑を 対象とした式では負の要因として, 樹冠面積 1 ha 以 上の緑地を対象とした式では正の要因として選択さ れ, 両者の間で逆の結果となった. また, 樹冠面積 1ha 未満の緑地を対象とした式では $100 \mathrm{~m}$ バッファ 内, 樹冠面積 $1 \mathrm{ha}$ 以上の緑地を対象とした式では $200 \mathrm{~m}$ バッファ内の変数が選択された.フィンランド では, 緑地の周囲がアパート街よりも個別住宅地で あるほうが野鳥の種数が多かったと報告されている

(Clergeau et al. 2001). 小規模緑地では, その場所 をおもな生息場所とする個体も緑地外の資源も利用 していると考えられるが，広い庭のあることが稀な 大阪市街地の低層住宅地は, 野鳥の生息にとつて好 ましいものではないようだ，一方，樹冠面積 1ha 以 上の緑地を対象とした式において, $200 \mathrm{~m}$ バッファ内 の低層住宅地率が正の要因となった理由としては, 低層住宅地が多い地域が市街地の中心から離れた郊 外であることと関係していることが考えられた。

\section{2. 都市緑地の樹林性鳥類の種組成とそれを決定す る要因}

TWINSPAN による群集分類の結果，3タイプの出 現傾向の異なる鳥類グループがあったことが明らか になった．どの都市緑地にも出現する鳥類グループ は, 都市鳥と呼ばれているような, 都会の生活に適 応した種からなっていた.もうひとつのグループは, 開放的な環境を好むムクドリやハシボソガラスから なっていた，そして残りひとつのグループは，シジ ユウカラやコゲラなどの森林性鳥類からなっていた. 種組成のパターンは，多くの種が記録された緑地で はそれ以下の種数の緑地に出現した種のほぼ全てを 含むという入れ子型の構造(夏原 2000)をしていた.

判別分析の結果, 種数の重回帰分析の結果之同様, 緑地内樹冠面積の増加が鳥類相を豊かにする要因, 周辺の道路用地率と商業地率が鳥類相を貧弱にする 要因となっていた。したがって, 都市緑地の樹林性 鳥類相を豊かにする方策としては, 樹木量を増加さ せるほか, 道路や商業地区・オフィスビル群によつ て阻害されている都市緑地への鳥類の自由な出入り を可能にするため, 街路樹緑化やビルの公開空地の 緑化を推進することも有効であると考えられる.

森林性鳥類が高頻度で出現した Aグループの緑地 
は，大阪市街地において野鳥にとつて良好な緑地之 いえ, 緑地内樹冠面積が大きく, 周囲に商業地が少 ない緑地であった（図 3 b)。このような森林性鳥類 の生息地を新たに市街地内に創出するには，5ha 前 後の樹林面積が目安といえる.しかし，同じ近畿地 方の京都市街地の社寺林では, 樹冠面積が 5ha もあ れば，繁殖期にエナガ Aegithalos caudatus，ヤマガラ Parus varius, イカル Eophona personata, ウグイス Cettia diphone といつた森林性鳥類も高頻度で生息 している (橋本 未発表)。したがって, 大阪市街地 の鳥類相はかなり貧弱であるといえる．公園では下 層植生が貧弱であることから，大阪市街地では，や ぶを住処とするウグイスが全く繁殖していない．ま た，大阪の公園では近年，樹林内に野宿者のテント が数多く見られ，森林の内部をおもな生活場所とし ている鳥類にとっては棲夕にくい状況にある.

\section{3. 今後の課題.}

鳥類相は，環境の変化だけでなく，鳥類の側の人 工環境への適応などによっても変化する．ヒヨドリ やキジバトはかつて山の鳥であったが，大阪では 1970 年代に都会に進出した（高田 1991）。またシジ ユウカラ, メジロ, カワラヒワ, ハシブトガラスも 大阪では 1980 年以降に繁殖を始めた種である(和田 1999).コゲラも近年になって都市域に進出してきた 種である.夏原（2000）は約 10 年前の大阪ではコゲ ラは 10ha 以下の孤立林では生息していなかったと 報告しているが，今回の調査ではコゲラは 4 地点で 記録され，その内の 2 地点は $10 \mathrm{ha}$ 未満の都市緑地で あった. コゲラは今後, さらに小さな緑地でも生息 するようになる可能性がある．また，2002 年繁殖期 にはヤマガラが大阪城公園で記録されるなど（和田 岳氏 私信), 大阪の鳥類相も少しずつ変化している. 和田（1999）も指摘しているように，ひょっとする と現時点ではそれぞれの緑地における種数の環境収 容力が飽和しておらず，移入率と絶滅率が平衡に達 していない可能性もある. 同じ地域における数年お きの鳥類相調査は, 都市環境の変化と鳥類の習性の 変化を知る上で，興味深い情報の収集になると考え られる。

\section{引用文献}

Clergeau, P., Jokimäki, J. and Savard, J. L. 2001. Are urban bird communities influenced by the bird diversity of adjacent landscapes? Journal of Applied Ecology 38: 1122-1134.
Fernández-Juricic, E. 2000a. Avifaunal use of wooded streets in an urban landscape. Conservation Biology 14: 513-521.

Fernández- Juricic, E. 2000b. Bird community composition patterns in urban parks of Madrid :The role of age, size and isolation. Ecological Research 15: 373-383.

Fernández-Juricic, E. and Jokimäki, J. 2001. A habitat island approach to conserving birds in urban landscapes: case studies from southern and northern Europe. Biodiversity and Conservation 10: 20232043.

Fukui, A. W. 1995. The role of the Brown-eared bulbul Hypsypetes amaurotis as a seed dispersal agent. Researches on Population Ecology 37: 211-218.

Gleason, H. A. 1922. On the relation between species and area. Ecology 3: 158-162.

羽田健三・中村浩志. 1970. カワラヒワの生活史に関 する研究. 鳥 20:41-59.

羽田健三・野沢進之輔. 1969. キジバトの生活史に関 する研究. 山階鳥類研究所報告 5: 72-84.

橋本啓史・夏原由博. 2002. ロジスティック回帰をも ちいた都市におけるシジュウカラの生息環境適合 度モデル. ランドスケープ研究 65: 539-542.

樋口広芳・塚本洋三・花輪伸一・武田宗也. 1982. 森. 林面積と鳥の種数との関係. Strix 1: 70-78.

Hill, M.O. 1979. TWINSPAN, a FORTRAN program for arranging multivariate data in an ordered two-way table by classification of the individuals and attributes. 30pp. Cornell University, Ithaca.

唐沢孝一. 1989. スズメのお宿は街のなか: 都市鳥の 適応戦略. 260pp. 中央公論社, 東京.

Kurosawa, R. and Askins. R.A. 1999. Difference in bird communities on the forest edge and in the forest interior: are there forest-interior specialists in Japan? Journal of Yamashina Institute for Ornithology 31: 6379.

中村登流. 1975. 日本における力ラ類群集構造の研 究 III.: カラ類の行動圈分布構造の比較. 山階鳥類 研究所報告 7:603-636.

夏原由博. 2000. 都市における自然景観創造. ランド スケープ研究 64: 135-137.

Natuhara, Y. and Imai, C. 1999. Prediction of species richness of breeding birds by landscape-tevel factors of urban woods in Osaka Prefecture, Japan. Biodiversity and Conservation 8: 239-253. 
小河原孝生. 1996. 都市の森: 生きものの生息環境づ くり. 緑の読本 38: 557-563.

大迫義人. 1992. 北海道東部地方斜里の防潮保安林 における早春期の鳥類相とラインセンサス法の問 題点. Strix 11: 299-305.

Opdam, P., van Dorp, D. and Ter Braak, C. F. J. 1984. The effect of isolation on the number of woodland birds in small woods in the Netherlands. Journal of Biogeography 11: 473-378.

大阪府土木部公園課. 2001. 大阪府都市公園一覧表. $299 p p$. 大阪府土木部公園課, 大阪.

佐野昌男. 1988. スズメ：人里の野鳥. $218 \mathrm{pp}$. 信濃每 日新聞社，長野.
Sanz, J.J. 2001. Exprimentally increased insectivorous bird density results in a reduction of caterpillar density and leaf damage to Pyrenean oak. Ecological Research 16: 387-394.

高田博. 1991. 大阪市の都市鳥. 全国主要都市の都市 鳥（都市鳥研究会編），89-92. 都市鳥研究会，東 京.

和田岳. 1999. 大阪市内の公園で繁殖する鳥の種数 について，大阪市立自然史博物館研究報告 53: $57-67$.

（受付 2002 年 9 月 2 日）

（受理 2003 年 9 月 26 日） 